\title{
Urbanisation-related land use change from forest and pasture into turf grass modifies soil nitrogen cycling and increases $\mathrm{N}_{2} \mathrm{O}$ emissions
}

\author{
Lona van Delden, David W. Rowlings, Clemens Scheer, and Peter R. Grace \\ Institute for Future Environments (IFE), Queensland University of Technology (QUT), Brisbane, QLD, Australia \\ Correspondence to: Lona van Delden (lona.vandelden@qut.edu.au)
}

Received: 19 May 2016 - Published in Biogeosciences Discuss.: 31 May 2016

Revised: 6 September 2016 - Accepted: 17 October 2016 - Published: 7 November 2016

\begin{abstract}
Urbanisation is becoming increasingly important in terms of climate change and ecosystem functionality worldwide. We are only beginning to understand how the processes of urbanisation influence ecosystem dynamics, making peri-urban environments more vulnerable to nutrient losses. Brisbane in South East Queensland has the most extensive urban sprawl of all Australian cities. This research estimated the environmental impact of land use change associated with urbanisation by examining soil nitrogen $(\mathrm{N})$ turnover and subsequent nitrous oxide $\left(\mathrm{N}_{2} \mathrm{O}\right)$ emissions using a fully automated system that measured emissions on a sub-daily basis. There was no significant difference in soil $\mathrm{N}_{2} \mathrm{O}$ emissions between the native dry sclerophyll eucalypt forest and an extensively grazed pasture, wherefrom only low annual emissions were observed amounting to 0.1 and $0.2 \mathrm{~kg} \mathrm{~N}_{2} \mathrm{O} \mathrm{ha}^{-1} \mathrm{yr}^{-1}$, respectively. The establishment of a fertilised turf grass lawn increased soil $\mathrm{N}_{2} \mathrm{O}$ emissions 18fold $\left(1.8 \mathrm{~kg} \mathrm{~N}_{2} \mathrm{O} \mathrm{ha}^{-1} \mathrm{yr}^{-1}\right)$, with highest emissions occurring in the first 2 months after establishment. Once established, the turf grass lawn presented relatively low $\mathrm{N}_{2} \mathrm{O}$ emissions for the rest of the year, even after fertilisation and rain events. Soil moisture was significantly higher, and mineralised $\mathrm{N}$ accumulated in the fallow plots, resulting in the highest $\mathrm{N}_{2} \mathrm{O}$ emissions $\left(2.8 \mathrm{~kg} \mathrm{~N}_{2} \mathrm{O} \mathrm{ha}^{-1} \mathrm{yr}^{-1}\right)$ and significant nitrate $\left(\mathrm{NO}_{3}^{-}\right)$losses, with up to $63 \mathrm{~kg} \mathrm{Nha}^{-1}$ lost from a single rain event due to reduced plant cover removal. The study concludes that urbanisation processes creating periurban ecosystems can greatly modify $\mathrm{N}$ cycling and increase the potential for losses in the form of $\mathrm{N}_{2} \mathrm{O}$ and $\mathrm{NO}_{3}^{-}$.
\end{abstract}

\section{Introduction}

Global urbanisation processes are becoming increasingly important in terms of global warming and ecosystem functionality. Urban populations worldwide have not only exceeded rural populations but are also predicted to account for all future population growth (United Nations, 2008). Urban sprawl and increasing population densities are causing severe land use changes from intact biomes and commercially focused agriculture into smaller residential properties with introduced species. This transition from rural to semi-rural, i.e. peri-urban, and urban environments is increasingly associated with development and construction processes and the extensive establishment of turf grass for residential backyards, public parks and sports grounds, and golf courses (IPCC, 2006). How these urbanisation processes influence ecosystem dynamics in biogeochemical cycling, and therefore contribute to ecosystem vulnerability and global warming, is only beginning to be understood.

The consequences of land use change from native vegetation to agriculture have been identified by several studies and include a loss in soil quality (structure and nutrient losses) and quantity (erosion), increased greenhouse gas (GHG) emissions, and a reduced potential for soil carbon (C) sequestration (Livesley et al., 2009; Grover et al., 2012). On the other hand, changing soils from agricultural to residential use in temperate climates has shown the potential to improve critical ecosystem services by (i) providing stormwater treatment, (ii) acting as a sink for atmospheric nitrogen $(\mathrm{N})$, and (iii) sequestering C (Golubiewski, 2006; Raciti et al., 2011).

Studies on the impact of these land use changes on climate change are few but suggest that urbanisation will alter biogeochemical cycling of $\mathrm{C}$ and $\mathrm{N}$ and associated nutrient turnover (Grimm et al., 2008). These biogeochemi- 
cal alterations induced by land use change interact with urban effects (Betts, 2007) such as the creation of heat islands through vegetation replacement and surface sealing, and they also increased local carbon dioxide concentration of over $500 \mathrm{ppm}$ around cities compared to $390 \mathrm{ppm}$ in natural environments (Pataki et al., 2007; IPCC, 2013). These changing local climatic conditions and their feedback effects onto natural ecosystems make peri-urban environments more vulnerable to nutrient losses and potential sources of GHG emissions. With peri-urban areas expanding worldwide it is most likely that these changing local climates will increasingly have an impact on global climate change, making the examination of GHG emissions from peri-urban land uses all the more urgent.

Nitrous oxide $\left(\mathrm{N}_{2} \mathrm{O}\right)$, along with carbon dioxide $\left(\mathrm{CO}_{2}\right)$ and methane $\left(\mathrm{CH}_{4}\right)$, is one of the major greenhouse gases with a global warming potential (GWP) nearly 300 times that of $\mathrm{CO}_{2}$ (IPCC, 2013). Nitrous oxide is produced principally by microorganisms during nitrification and denitrification processes from mineral $\mathrm{N}\left(\mathrm{NH}_{4}^{+}\right.$and $\left.\mathrm{NO}_{3}^{-}\right)$in the soil. The production of $\mathrm{N}_{2} \mathrm{O}$ is influenced by a number of soil parameters including substrate availability; temperature; and the availability of oxygen, which is dependent on water content and texture of the soil (Rowlings et al., 2015). With predicted climatic changes, Australia's ancient and fragile soils will most likely be affected in their balance between GHG gas emissions and consumption (Baldock et al., 2012). Management practices such as fertilisation and irrigation enhance $\mathrm{N}_{2} \mathrm{O}$ production in the soil by increasing the mineral $\mathrm{N}$ content and limiting the oxygen availability (Scheer et al., 2008; Rowlings et al., 2013). Turf grass is the most highly managed land use of peri-urban environments in terms of fertilisation, irrigation, and frequent mowing, and it therefore has a high potential for $\mathrm{N}_{2} \mathrm{O}$ emissions.

Research on urban and peri-urban areas in temperate zones suggests that urbanisation can result in emissions comparable to agriculture, with the intensive management of these peri-urban areas expanding rapidly worldwide (Milesi et al., 2005; Groffman and Pouyat, 2009). More than half the world's 7.2 billion population currently occupies $2.4 \%$ of the global terrestrial land surface in urban areas (Potere and Schneider, 2007; United Nations, 2013). While peri-urban environments are often considered too small to be of consequence, the rapid growth of peri-urban areas has resulted in over $160000 \mathrm{~km}^{-2}$ being converted to turf grass lawn in the USA alone, 3 times more than any other irrigated crop in the country (Milesi et al., 2005). In Australia about $60 \%$ of all anthropogenic $\mathrm{N}_{2} \mathrm{O}$ emissions come from cropped and grazed soils (AGO, 2010), and the first GHG estimations from turf grass establishment support the emission intensity reported from temperate zones (van Delden et al., 2016). The area under turf grass is consistently growing in Australia with up to 17320 ha in turf sales with an approximate gross value production of AUD 240 million per annum (ABS, 2012; Turf Australia, 2012). Detailed estimates of turf grass cover, how- ever, currently do not exist for the Australian continent and other subtropical regions like South-east Asia, China, India, or Mexico. Urbanisation is currently neglected in modelled IPCC climate scenarios, mainly due to limited data on $\mathrm{C}$ and $\mathrm{N}$ processes in urban and peri-urban environments (IPCC, 2006, 2013).

This study therefore aims to identify the impact of those land use changes associated with urbanisation on annual $\mathrm{N}_{2} \mathrm{O}$ emissions and their driving parameters in subtropical periurban environments. Following a short-term (80-day) GHG sampling campaign focussing on lawn establishment (van Delden et al., 2016), a fully automated closed static chamber system was used to continuously monitor $\mathrm{N}_{2} \mathrm{O}$ fluxes together with soil biogeochemical processes over a full year to determine the seasonal impact of construction work, fallows, and conversion from extensively grazed pasture to turf grass lawn. This study's high-resolution flux measurements and supporting soil $\mathrm{N}$ mineralisation illustrate the vulnerability of ecosystems to urbanisation processes and the potential impact on $\mathrm{N}$ cycling and $\mathrm{N}_{2} \mathrm{O}$ emissions.

\section{Materials and method}

\subsection{Site description}

The study was conducted at the Samford Ecological Research Facility (SERF) in the Samford Valley, $20 \mathrm{~km}$ from Brisbane in South East Queensland (SEQ), Australia. The Samford Valley covers an area of approximately $82 \mathrm{~km}^{2}$ and is surrounded by mountains to the north, west, and south. Mostly cleared in the early 1900s, the valley was developed in the 1960s for dairy and beef cattle as well as intensive agriculture including banana and pineapple. Samford's population density has increased rapidly, almost doubling from 1996 to 2006, causing land use change from predominately rural to residential properties (Moreton Bay Regional Council, 2011). As a result, SERF contains the last remnant forest of the valley floor. The valley is influenced by a humid subtropical climate with seasonal summer rain. The longterm mean annual precipitation is $1110 \mathrm{~mm}$ with mean annual minimum and maximum temperatures of 13 and $25.6^{\circ} \mathrm{C}$ respectively (BOM, 2015). The soil at the experimental site is characterised by a strong texture contrast between the A and $\mathrm{B}$ horizon and is classified as brown Chromosol according to the Australian soil classification (Isbell, 2002) and Planosol according to the World Reference Base (WRB, 2015).

\subsection{Experimental design}

This study examined the impact of land use change from a native forest to well-established pasture, turf grass lawn, and fallow soil without plant cover using the same sampling campaign setup as van Delden et al. (2016). Each land use treatment included three replicated plots, $2 \mathrm{~m}$ wide by $10 \mathrm{~m}$ long and separated by $0.5 \mathrm{~m}$ of pasture as a buffer zone. The turf 
grass lawn and fallow treatments were established within the well-established pasture to create a randomised plot design, $50 \mathrm{~m}$ from the native forest. The SERF native forest (dry sclerophyll eucalypt forest) was used as the baseline for historical land use and was unmanaged. The well-established Chloris gayana pasture represents rural development in the area and has been extensively grazed for the last 15 years. Livestock were excluded over the course of the study, and the pasture grass was slashed 5 times to ensure it did not exceed the maximum height of the GHG measurement chamber.

The turf grass lawn was established from the wellestablished pasture by removing $5 \mathrm{~cm}$ of topsoil with grass roots. The soil was rotary-hoed twice to a depth of $15 \mathrm{~cm}$, and blue couch (Digitaria didactyla) turf rolls were planted with $50 \mathrm{~kg} \mathrm{~N} \mathrm{ha}^{-1}$ fertilisation (13 June 2013) to aid in establishment. Over the experimental year the turf grass lawn was fertilised twice more (26 October 13, 6 March 2014) with $50 \mathrm{~kg} \mathrm{Nha}^{-1}$ and irrigated, in all $150 \mathrm{~kg} \mathrm{Nha}^{-1} \mathrm{yr}^{-1}$ of Prolific Blue AN fertiliser (12.0\% nitrogen, $5.2 \%$ phosphorus, $14.1 \%$ potassium, $1.2 \%$ magnesium) with two-thirds of the $\mathrm{N}$ content by mass in the ammonium form. The turf grass lawn was irrigated only enough to ensure its survival, with a total of $30 \mathrm{~mm}$ applied during drier months as well as after fertilisation. The turf grass was mowed with the clippings removed as soon as the grass grew to the maximum chamber height - once in spring, twice in summer, and twice in autumn - and kept free of weeds manually at all times. Fertilisation rates were based on half the local industry practice recommendation. Infrequent mowing represents the normal management for residential properties in this region and is normally in response to increased growth in the wetter and warmer summer months.

The fallow treatment simulated the impact of transitional processes such as construction work and plant cover replacement. In the fallow treatment, the grass cover was removed and the bare soil was rotary-hoed twice to a depth of $15 \mathrm{~cm}$. The fallow treatment was kept free from plant cover over the full experimental year with a non-selective herbicide (Biactive, $360 \mathrm{~g} \mathrm{~L}^{-1}$ glyphosate) and a broadleaf herbicide (Double Time, $340 \mathrm{gL}^{-1} \mathrm{MCPA}+80 \mathrm{gL}^{-1}$ dicambra). During the experimental year, high-resolution sub-daily $\mathrm{N}_{2} \mathrm{O}$ flux measurements were combined with mineral $\mathrm{N}$ analysis and site-specific climate and soil moisture measurements.

\section{$2.3 \quad \mathrm{~N}_{2} \mathrm{O}$ flux measurements}

Nitrous oxide fluxes were determined from mid-June 2013 to mid-June 2014 using an automated sampling system as detailed by Scheer et al. (2014), extending the turf grass establishment phase documented by van Delden et al. (2016) into a full measurement year. The pneumatically operated $50 \mathrm{~cm} \times 50 \mathrm{~cm} \times 15 \mathrm{~cm}$ high, clear acrylic glass chambers were secured to stainless steel bases, permanently inserted $10 \mathrm{~cm}$ into the ground. The chambers were moved each week between two bases per treatment plot to minimise the influ- ence of the chamber microclimate, while measurements were analysed continuously. The chambers were connected to an automated sampling system and an in situ gas chromatograph (SRI GC8610, Torrance, CA, USA) equipped with a ${ }^{63} \mathrm{Ni}$ electron capture detector (ECD) for $\mathrm{N}_{2} \mathrm{O}$. One replicate chamber from each of the four treatments was closed for $1 \mathrm{~h}$, and four headspace gas concentrations measured at $15 \mathrm{~min}$ intervals, followed a known calibration standard $(0.5 \mathrm{ppm}$ $\mathrm{N}_{2} \mathrm{O}$, Air Liquide, Houston, TX, USA). This process was repeated for the remaining two replicate chambers over a full cycle of $3 \mathrm{~h}$, allowing eight flux measurements to be calculated per day for each of the 12 chambers.

\subsection{Auxiliary measurements}

Soil samples were taken fortnightly from all replicated treatment plots over the experimental year and divided into two depths $(0-10,10-20 \mathrm{~cm}) . \mathrm{NH}_{4}^{+}$and $\mathrm{NO}_{3}^{-}$were extracted from the soil using a $1: 5 \mathrm{KCl}$ solution with $20 \mathrm{~g}$ of fresh soil with additional soil moisture determination at $105^{\circ} \mathrm{C}$ to identify the dry soil weight for the mineral $\mathrm{N}$ calculation as described by Carter and Gregorich (2007). The extract was analysed for mineral $\mathrm{N}\left(\mathrm{NH}_{4}^{+}\right.$and $\left.\mathrm{NO}_{3}^{-}\right)$with an AQ2+ discrete analyser (SEAL Analytical WI, USA). The net mineralisation rate was determined from differences in mineral $\mathrm{N}$ content between sampling dates (Hart et al., 1994). Soil moisture and temperature for each treatment were collected using a time-domain reflectometer (TDR) probe (HydroSense CD 620 CSA) and a PT100 probe (IMKO Germany). Soil moisture was then converted with the treatmentspecific bulk density (BD) to water-filled pore space (WFPS). Soil samples were taken for site characterisation with a hydraulic soil corer to $1 \mathrm{~m}$ depth, air-dried, and sieved to $2 \mathrm{~mm}$. Particle size analysis for soil texture as well as $\mathrm{BD}, \mathrm{pH}$, and electrical conductivity (EC) analysis was undertaken according to Carter and Gregorich (2007). The cation exchange capacity (CEC) was determined based on Rayment and Higginson (1992). Total C and N content of air-dried soil and plant material was determined by dry combustion (CNS2000, LECO Corporation, St. Joseph, MI, USA) from ground samples.

\subsection{Flux calculations and statistical analysis}

Fluxes were calculated from the slope of the linear increase or decrease of the four concentrations measured over the closure time and corrected for chamber temperature and atmospheric pressure using the procedure outlined by Knowles and Singh (2003) and Scheer et al. (2014). The linear regression coefficient $\left(r^{2}\right)$ was calculated and used as a quality check for fluxes above the detection limit to assure linearity of the gas concentration increase. Flux rates were discarded when $r^{2}$ was $<0.85$ for $\mathrm{N}_{2} \mathrm{O}$ fluxes (Scheer et al., 2013). Daily fluxes from the automated chambers were calculated by averaging sub-daily measurements for each chamber over 
Table 1. SERF site characteristics.

\begin{tabular}{|c|c|c|c|c|c|c|c|c|c|c|c|}
\hline Parameters & & & & & & & & & & & \\
\hline Longitude & & & & & & $152^{\circ} 52^{\prime} 37$ & $3^{\prime \prime} \mathrm{E}$ & & & & \\
\hline Latitude & & & & & & $27^{\circ} 23^{\prime} 22.2$ & $11^{\prime \prime} \mathrm{S}$ & & & & \\
\hline Altitude & & & & & & $60 \mathrm{~m}$ & & & & & \\
\hline Slope & & & & & & $2^{\circ}$ & & & & & \\
\hline Mean annual min temp. & & & & & & $13^{\circ} \mathrm{C}^{\mathrm{a}}$ & & & & & \\
\hline Mean annual max temp. & & & & & & $25.6^{\circ} \mathrm{C}^{\mathrm{a}}$ & & & & & \\
\hline Mean annual rain & & & & & & $1110 \mathrm{~mm}^{\mathrm{a}}$ & & & & & \\
\hline Soil profile & Horizons ${ }^{b}$ & $\begin{array}{r}\text { Depths } \\
(\mathrm{cm})\end{array}$ & $\begin{array}{r}\text { Sand } \\
(\%)\end{array}$ & $\begin{array}{l}\text { Silt } \\
(\%)\end{array}$ & $\begin{array}{r}\text { Clay } \\
(\%)\end{array}$ & $\begin{array}{c}\mathrm{BD} \\
\left(\mathrm{g} \mathrm{cm}^{-3}\right)\end{array}$ & $\mathrm{pH}$ & $\begin{array}{r}\mathrm{EC} \\
(\mu \mathrm{S})\end{array}$ & $\begin{array}{c}\text { CEC } \\
\left(\mathrm{meq}+100 \mathrm{~g}^{-1}\right)\end{array}$ & $\begin{array}{r}\text { Total C } \\
(\%)\end{array}$ & $\begin{array}{r}\text { Total N } \\
(\%)\end{array}$ \\
\hline \multirow[t]{3}{*}{ Pasture } & A1 & $0-17$ & 70 & 24 & 6 & 1.4 & 5.4 & 46 & 4.0 & 1.5 & 0.12 \\
\hline & $\mathrm{A} 2$ & $17-45$ & 74 & 18 & 8 & 1.6 & 6.0 & 10 & 0.9 & 0.9 & 0.07 \\
\hline & B2 & $45-92$ & 9 & 18 & 73 & 1.8 & 6.1 & 31 & 11.8 & 0.4 & 0.03 \\
\hline \multirow[t]{3}{*}{ Forest } & A1 & $0-20$ & 75 & 18 & 7 & 1.4 & 5.5 & 29 & 2.8 & 1.8 & 0.14 \\
\hline & $\mathrm{A} 2$ & $20-47$ & 78 & 15 & 7 & 1.5 & 5.6 & 30 & 0.9 & 1.1 & 0.08 \\
\hline & B2 & $47-70$ & 41 & 7 & 52 & 1.7 & 5.6 & 30 & 11.8 & 0.2 & 0.02 \\
\hline
\end{tabular}

${ }^{a}$ Long-term means by Commonwealth Bureau of Meteorology, Australian Government (BOM, 2015). ${ }^{\mathrm{b}}$ According to the Australian soil classification.

Table 2. Seasonal and cumulative rain, number of rain events and seasonal and annual averages of minimum and maximum temperatures of the experimental year.

\begin{tabular}{|c|c|c|c|c|}
\hline & \multirow{2}{*}{$\begin{array}{r}\text { Sum rain } \\
(\mathrm{mm})\end{array}$} & \multirow{2}{*}{$\begin{array}{l}\text { Number of } \\
\text { rain events* }\end{array}$} & \multicolumn{2}{|c|}{ Avg temperature $\left({ }^{\circ} \mathrm{C}\right)$} \\
\hline & & & Min & Max \\
\hline Winter & 51.2 & 0 & 11.5 & 22.6 \\
\hline Spring & 248.2 & 5 & 16.7 & 28.2 \\
\hline Summer & 137.2 & 3 & 20.7 & 30.2 \\
\hline \multirow[t]{2}{*}{ Autumn } & 303.2 & 3 & 17.6 & 27.5 \\
\hline & 739.8 & 11 & 16.7 & 27.1 \\
\hline
\end{tabular}

* Rain event if sum $>10 \mathrm{~mm}$ per day.

the $24 \mathrm{~h}$ period. The detection limit determined for the gas sampling system was $\pm 1.2 \mathrm{~g} \mathrm{~N}_{2} \mathrm{Oha}^{-1} \mathrm{~d}^{-1}$. Gaps in the data set were filled by linear interpolation across missing days.

Statistical analysis was undertaken using SPSS Statistics 21.0 (IBM Corp., Armonk, NY). Non-normal distribution meant all cumulative data were log-transformed for analysis of variance (ANOVA) using Games-Howell as the post hoc test. Daily $\mathrm{N}_{2} \mathrm{O}$ flux differences between treatments were interpreted by plotting $95 \%$ confidence intervals using $\mathrm{R}$ studio. A significant difference of $p<0.05$ between treatments was assumed in case the confidence intervals of all treatments were not overlapping. A Spearman's rho correlation analysis was used to examine relationships between gas fluxes, soil chemistry, soil moisture, and temperature. The significance value $(p)$ is shown for each analysis, as well as the correlation coefficient $(r)$ with its significance level $\left(p<0.05^{*}\right.$, $\left.p<0.01^{* *}\right)$.

\section{Results}

\subsection{Site characteristics}

The site received $740 \mathrm{~mm}$ of rain during the experimental year, substantially less than the long-term average (Table 1). Wet-season rainfall was delayed compared to the historic average, with less than half the rainfall in summer (December to February) compared to autumn (March to May; Table 2). Substantial out-of-season rain also fell in the spring with over $200 \mathrm{~mm}$ in November alone. Rainfall was highly episodic, with the highest daily rain event of $108.8 \mathrm{~mm}$ in March 2014. The mean annual minimum and maximum temperatures for the experimental year were 16.7 and $27.1^{\circ} \mathrm{C}$ respectively, and light ground frost occurred twice in $\mathrm{Au}-$ gust. The turf grass and fallow treatment were established within the pasture and therefore share the same soil profile with its characteristics, except for bulk density in the A1 horizon, which changed after the turf grass establishment from 1.4 to $1.2 \mathrm{~g} \mathrm{~cm}^{-3}$. The CEC of the sandy topsoil was very low, and slightly higher in the A1 compared to the A2 horizon due to the higher soil organic matter as indicated by the total $\mathrm{C}$ and $\mathrm{N}$ content. Nutrient removal in turf grass clippings added up to $1.8 \mathrm{tCha}^{-1} \mathrm{yr}^{-1}$ and $30 \mathrm{~kg} \mathrm{Nha}^{-1} \mathrm{yr}^{-1}$ lost from the system during the experiment year respectively. The turf's biomass production was approximately $6.3 \mathrm{kgCha}^{-1} \mathrm{~d}^{-1}$ and $0.13 \mathrm{~kg} \mathrm{Nha}^{-1} \mathrm{~d}^{-1}$ in dry matter respectively but varied widely depending on fertilisation and available water with a maximum growth of $10.4 \mathrm{~kg} \mathrm{Cha}^{-1} \mathrm{~d}^{-1}$. 
Table 3. Annual mineral $\mathrm{N}$ averages of $\mathrm{NH}_{4}^{+}-\mathrm{N}$ and $\mathrm{NO}_{3}^{-}-\mathrm{N}$ at $0-20 \mathrm{~cm}$ soil depth, WFPS, and daily maximum and average $\mathrm{N}_{2} \mathrm{O}$ fluxes from all treatments with their cumulative annual fluxes over the experimental year with their standard error.

\begin{tabular}{lrrrccc}
\hline & $\begin{array}{r}\mathrm{NH}_{4}^{+}-\mathrm{N} \\
\left(\mathrm{kg} \mathrm{ha}^{-1}\right)\end{array}$ & $\begin{array}{r}\mathrm{NO}_{3}^{-}-\mathrm{N} \\
\left(\mathrm{kg} \mathrm{ha}^{-1}\right)\end{array}$ & $\begin{array}{r}\text { WFPS } \\
(\%)\end{array}$ & $\begin{array}{c}\text { Max daily flux } \\
\left(\mathrm{g} \mathrm{N}_{2} \mathrm{O} \mathrm{ha}^{-1} \mathrm{~d}^{-1}\right)\end{array}$ & $\begin{array}{c}\text { Avg daily flux } \\
\left(\mathrm{g} \mathrm{N}_{2} \mathrm{O} \mathrm{ha}^{-1} \mathrm{~d}^{-1}\right)\end{array}$ & $\begin{array}{c}\text { Annual flux } \\
\left(\mathrm{kg} \mathrm{N}_{2} \mathrm{O} \mathrm{ha}^{-1} \mathrm{yr}^{-1}\right)\end{array}$ \\
\hline Forest & $13.7^{\mathrm{a}} \pm 1.2$ & $3.9^{\mathrm{a}} \pm 0.6$ & $23^{\mathrm{a}}$ & 8.1 & $0.4^{\mathrm{a}} \pm 0.1$ & $0.1^{\mathrm{a}} \pm 0.03$ \\
Pasture & $17.4^{\mathrm{b}} \pm 1.4$ & $1.1^{\mathrm{b}} \pm 0.3$ & $42^{\mathrm{b}}$ & 18.3 & $0.6^{\mathrm{a}} \pm 0.1$ & $0.2^{\mathrm{a}} \pm 0.2$ \\
Turf grass & $21.9^{\mathrm{bc}} \pm 2.4$ & $8.9^{\mathrm{c}} \pm 2.5$ & $43^{\mathrm{b}}$ & 83.0 & $4.9^{\mathrm{b}} \pm 0.6$ & $1.8^{\mathrm{b}} \pm 0.3$ \\
Fallow & $26.0^{\mathrm{c}} \pm 1.9$ & $35.2^{\mathrm{d}} \pm 5.6$ & $55^{\mathrm{c}}$ & 123.8 & $7.7^{\mathrm{b}} \pm 1.0$ & $2.8^{\mathrm{b}} \pm 1.0$ \\
\hline
\end{tabular}

abcd Different letters indicate significant differences between treatments based on $p<0.05$.

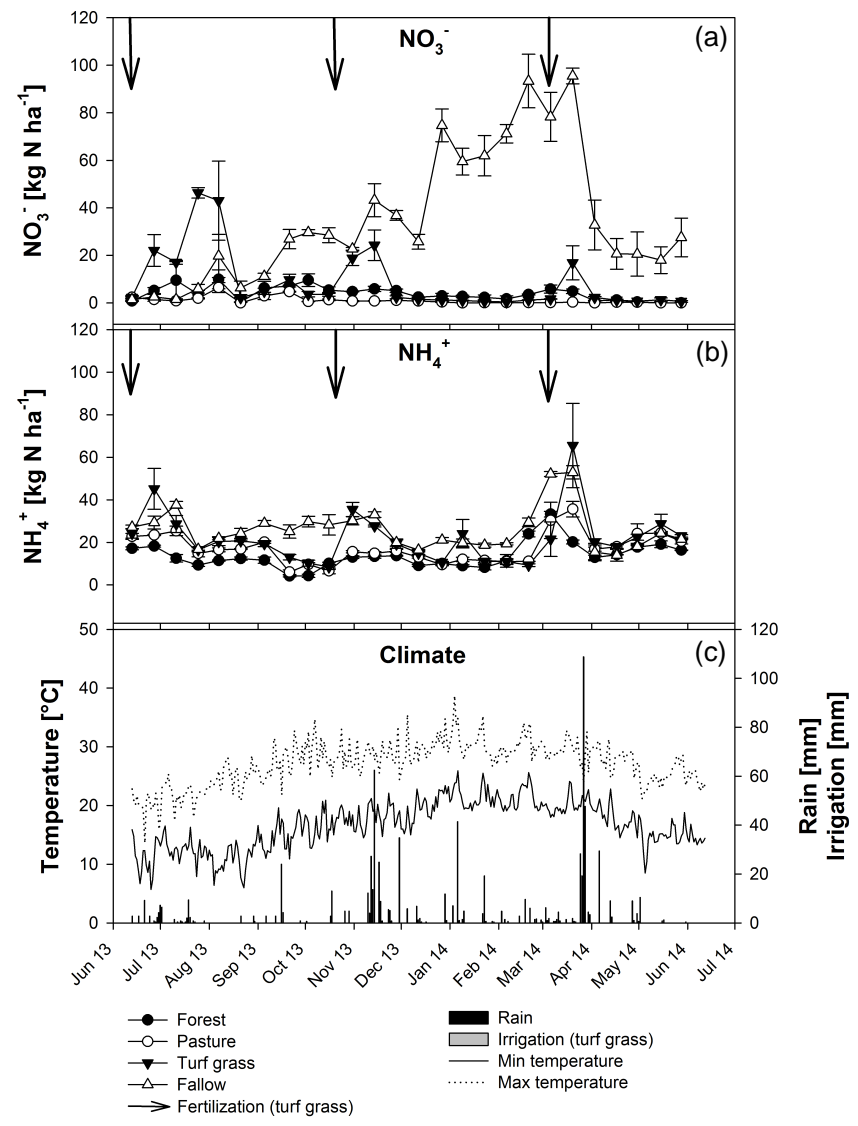

Figure 1. Annual soil $\mathrm{NO}_{3}^{-}$(a) and $\mathrm{NH}_{4}^{+}$(b) content variations from forest, pasture, turf grass, and fallow averaged across replicates $(n=3)$ and summed for separate analysed soil depths of $0-10$ and $10-20 \mathrm{~cm}$ with the climatic conditions (c) for the experimental year 2013/2014 as well as fertilisation and irrigation indication for the turf grass treatment.

\subsection{Environmental parameters}

The lowest WFPS recorded during the experimental year was $13 \%$ in the forest, with the highest occurring in the pasture, which briefly reached saturation in March 2014 (Fig. 3). In all treatments, the lowest WFPS occurred in spring and sum- mer with an average of 33 and $32 \%$ respectively, together with the highest average maximum daily temperatures of 28 and $30^{\circ} \mathrm{C}$. While the highest seasonal WFPS for all treatments occurred in winter, the maximum WFPS occurred during autumn after the heavy rain in March 2014. The forest had significantly lower WFPS throughout the experimental year than all other treatments $(p<0.01$, Table 3$)$, while the fallow had significantly higher WFPS $(p<0.01)$. No significant difference in WFPS was observed between pasture and turf grass $(p>0.05)$, although during spring, summer, and autumn turf grass had lower minimum and maximum values than the pasture. The fallow had significantly higher and forest significantly lower WFPS than pasture and turf grass $(p<0.01)$ throughout the experimental year.

\subsection{Temporal variability of mineral nitrogen}

Averaged over the experimental year, the fallow treatment had the highest $\mathrm{NH}_{4}^{+}$and $\mathrm{NO}_{3}^{-}$content across the top $20 \mathrm{~cm}$ soil profile, followed by turf grass, pasture, and forest (Table 3). These differences in mineral $\mathrm{N}$ were significant for all treatments $(p<0.01)$ except between pasture and forest $(p>0.05)$. The $0-10 \mathrm{~cm}$ depth had higher average total mineral $\mathrm{N}$ than the $10-20 \mathrm{~cm}$ depth for all treatments, with significant differences between all treatments $(p<0.01)$. In the 10 $20 \mathrm{~cm}$ soil depth only the fallow had significantly higher total mineral $\mathrm{N}, \mathrm{NH}_{4}^{+}$, and $\mathrm{NO}_{3}^{-}$contents $(p<0.01)$. Soil $\mathrm{NH}_{4}^{+}$ showed relatively little temporal variation and remained consistently above $3 \mathrm{~kg} \mathrm{NH}_{4}^{+} \mathrm{ha}^{-1}$, while $\mathrm{NO}_{3}^{-}$decreased substantially after rain events and fell below detection limit several times in all treatments but the fallow (Fig. 1).

Total mineral $\mathrm{N}$ in the forest ranged from 8 to $40.1 \mathrm{~kg} \mathrm{~N} \mathrm{ha}^{-1} 20 \mathrm{~cm}^{-1}$ throughout the year with marginally higher mineral $\mathrm{N}$ content at $0-10$ than $10-20 \mathrm{~cm}$, with 9.7 and $8 \mathrm{~kg} \mathrm{Nha}^{-1}$ respectively. Total mineral $\mathrm{N}$ in the pasture ranged from 5.1 to $42.4 \mathrm{~kg} \mathrm{Nha}^{-1} 20 \mathrm{~cm}^{-1}$, with a comparable distribution in depth to the $0-10$ and $10-20 \mathrm{~cm}$ forest soil with 10.7 and $7.8 \mathrm{~kg} \mathrm{Nha}^{-1}$ respectively. Total mineral $\mathrm{N}$ in the turf grass soil ranged from 9.1 to $127.6 \mathrm{~kg} \mathrm{Nha}^{-1}$ $20 \mathrm{~cm}^{-1}$. The turf grass had twice as much mineral $\mathrm{N}$ at $0-10$ than $10-20 \mathrm{~cm}$ depths, with 20.7 and $10.1 \mathrm{~kg} \mathrm{~N} \mathrm{ha}^{-1}$ respectively. A short-term increase in both $\mathrm{NH}_{4}^{+}$and $\mathrm{NO}_{3}^{-}$content 


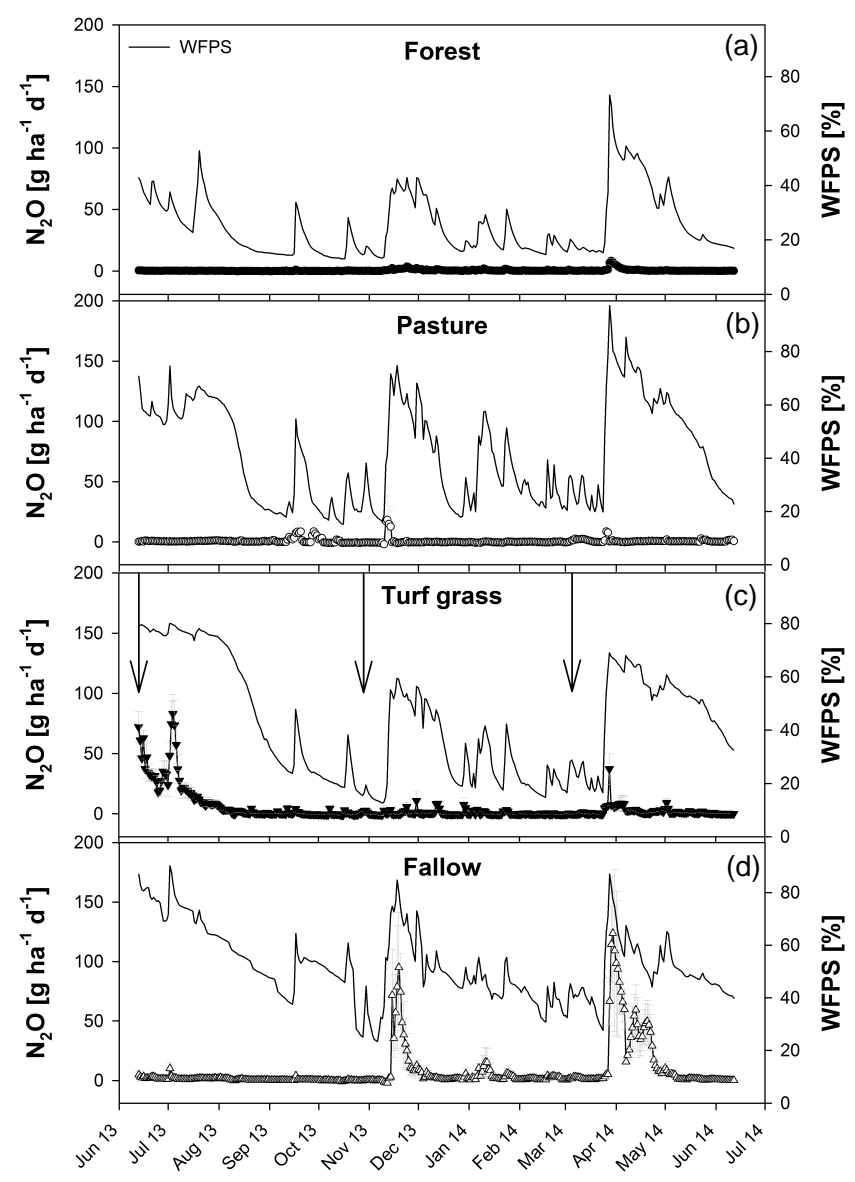

Figure 2. Daily $\mathrm{N}_{2} \mathrm{O}$ flux averages (max eight fluxes per day for three replicates each) with standard errors $(N=3)$ over the experimental year 2013/2014 for forest (a), pasture (b), turf grass (c), and fallow (d) with the treatment-specific water-filled pore space (WFPS).

in the soil was evident after fertilisation in June, October, and March, which decreased to the background levels after approximately 1 month. Total mineral $\mathrm{N}$ contents in the fallow soil ranged from 19.7 to $160.7 \mathrm{~kg} \mathrm{Nha}^{-1} 20 \mathrm{~cm}^{-1}$, with about two-thirds of the mineral $\mathrm{N}$ being located in the upper $10 \mathrm{~cm}$. All main changes in the fallow's total mineral $\mathrm{N}$ content were caused by variations in $\mathrm{NO}_{3}^{-}$rather than $\mathrm{NH}_{4}^{+}$. The $\mathrm{NO}_{3}^{-}$content increased in the fallow until the major rain event in March, when it dropped from 95.5 to $32.8 \mathrm{~kg} \mathrm{Nha}^{-1} 20 \mathrm{~cm}^{-1}$. From the linear increase in mineral $\mathrm{N}$ content within the upper $10 \mathrm{~cm}$ between January and March 2014 a soil mineralisation rate of $0.6 \mathrm{~kg} \mathrm{~N} \mathrm{ha}^{-1} \mathrm{~d}^{-1}$ was estimated.

\subsection{Temporal variation of $\mathrm{N}_{2} \mathrm{O}$ fluxes}

Daily $\mathrm{N}_{2} \mathrm{O}$ fluxes across all treatments ranged from extended periods of close to 0 to over $123 \mathrm{~g} \mathrm{~N}_{2} \mathrm{O} \mathrm{ha}^{-1} \mathrm{~d}^{-1}$ from the fallow when WFPS was highest after heavy-rain events (Fig. 2).

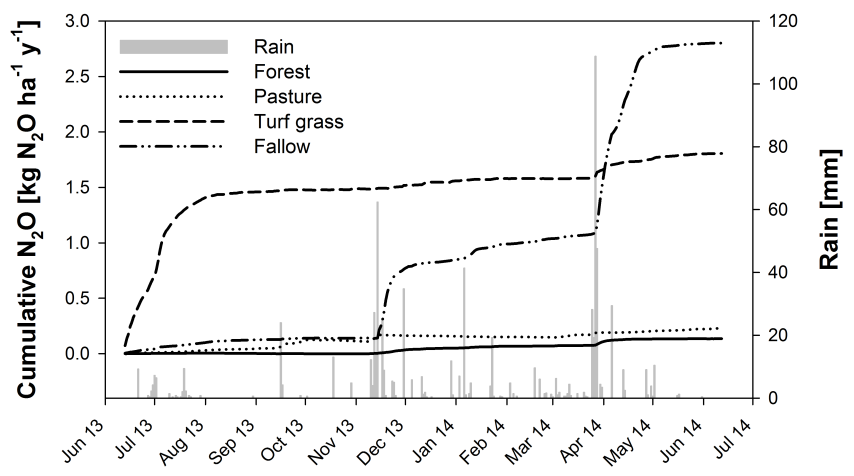

Figure 3. Cumulative daily $\mathrm{N}_{2} \mathrm{O}$ fluxes $(n=3)$ for forest, pasture, turf grass, and fallow with rainfall for the experimental year $2013 / 2014$.

The $\mathrm{N}_{2} \mathrm{O}$ fluxes from turf grass were more often significantly different on a daily basis than any other treatment with 76 days $(21 \%)$ of the experimental year; $80 \%$ of this difference occurred in the first 2 months after establishment. This was followed by the forest with 65 days (18\%), fallow with 58 days (16\%), and pasture with 29 days (8\%). Daily $\mathrm{N}_{2} \mathrm{O}$ fluxes from the forest soil showed no substantial temporal variation throughout the experimental year, with minor emission peaks up to $8.1 \mathrm{~g} \mathrm{~N}_{2} \mathrm{O} \mathrm{ha}^{-1} \mathrm{~d}^{-1}$ after large rain events $(>60 \mathrm{~mm})$ in November and March. From September until October one of the two bases in one pasture replicate emitted substantially more $\mathrm{N}_{2} \mathrm{O}$ than the other replicates; however, the exact cause of this is unknown. Without these spatially variable emissions, the annual flux would have been about $40 \%$ lower and therefore comparable to the forest $\mathrm{N}$ loss of $0.09 \mathrm{~kg} \mathrm{Nha}^{-1} \mathrm{yr}^{-1}$. During the initial emission peak between June and August the daily average $\mathrm{N}_{2} \mathrm{O}$ flux from the turf grass was $24 \mathrm{~g} \mathrm{~N}_{2} \mathrm{O} \mathrm{ha}^{-1} \mathrm{~d}^{-1}$, reaching a maximum of $83 \mathrm{~g} \mathrm{~N}_{2} \mathrm{O} \mathrm{ha}^{-1} \mathrm{~d}^{-1}$. Excluding this initial emission peak, daily $\mathrm{N}_{2} \mathrm{O}$ fluxes from the turf grass averaged $1.2 \mathrm{~g} \mathrm{~N}_{2} \mathrm{O} \mathrm{ha}^{-1} \mathrm{~d}^{-1}$. The highest annual $\mathrm{N}_{2} \mathrm{O}$ flux was measured in the fallow from only three large peaks over 19, 10, and 44 consecutive days after rain events, which together accounted for $85 \%$ of the total $\mathrm{N}$ losses. Over a third of the significantly high daily $\mathrm{N}_{2} \mathrm{O}$ fluxes in the fallow occurred from the heavy-rain event in March 2014.

Annual $\mathrm{N}_{2} \mathrm{O}$ losses were highest in the fallow and turf grass treatments, totalling 1.78 and $1.15 \mathrm{~kg} \mathrm{Nha}^{-1} \mathrm{yr}^{-1} \mathrm{re}-$ spectively, compared to the pasture and forest losses of 0.15 and $0.09 \mathrm{~kg} \mathrm{~N} \mathrm{ha}^{-1} \mathrm{yr}^{-1}(p<0.01$, Table 3$)$. About $80 \%$ of the annual $\mathrm{N}_{2} \mathrm{O}$ losses in the turf occurred in the first 8 weeks after establishment (Fig. 3). Mineral $\mathrm{N}$ fertiliser input of $150 \mathrm{~kg} \mathrm{~N} \mathrm{ha}^{-1} \mathrm{yr}^{-1}$ and the yearly $\mathrm{N}_{2} \mathrm{O}-\mathrm{N}$ losses from the turf grass lawn corrected for background emissions (zero $\mathrm{N}$ fertilisation) from the pasture resulted in an emission factor (EF) of $0.7 \%$ (Kroeze et al., 1997). 
Table 4. Spearman's rho correlation coefficient between $\mathrm{N}_{2} \mathrm{O}$ fluxes and mineral N, WFPS, and temperature for each treatment.

\begin{tabular}{lccc|cc}
\hline & \multicolumn{3}{c|}{$\mathrm{N}_{2} \mathrm{O}$} & \multicolumn{2}{c}{ Mineral N } \\
\cline { 2 - 6 } & Mineral N & WFPS & Temperature & WFPS & Temperature \\
\hline Forest & -0.39 & $0.61^{*}$ & $0.40^{*}$ & 0.07 & -0.17 \\
Pasture & $0.49^{*}$ & $0.30^{*}$ & $-0.46^{*}$ & $0.39^{*}$ & $-0.41^{*}$ \\
Turf grass & $0.47^{*}$ & $0.78^{*}$ & $-0.45^{*}$ & $0.47^{*}$ & $-0.50^{*}$ \\
Fallow & -0.0 & $0.43^{*}$ & $0.20^{*}$ & $-0.61^{*}$ & $0.72^{*}$ \\
\hline
\end{tabular}

* Correlation coefficient significant with $p<0.01$.

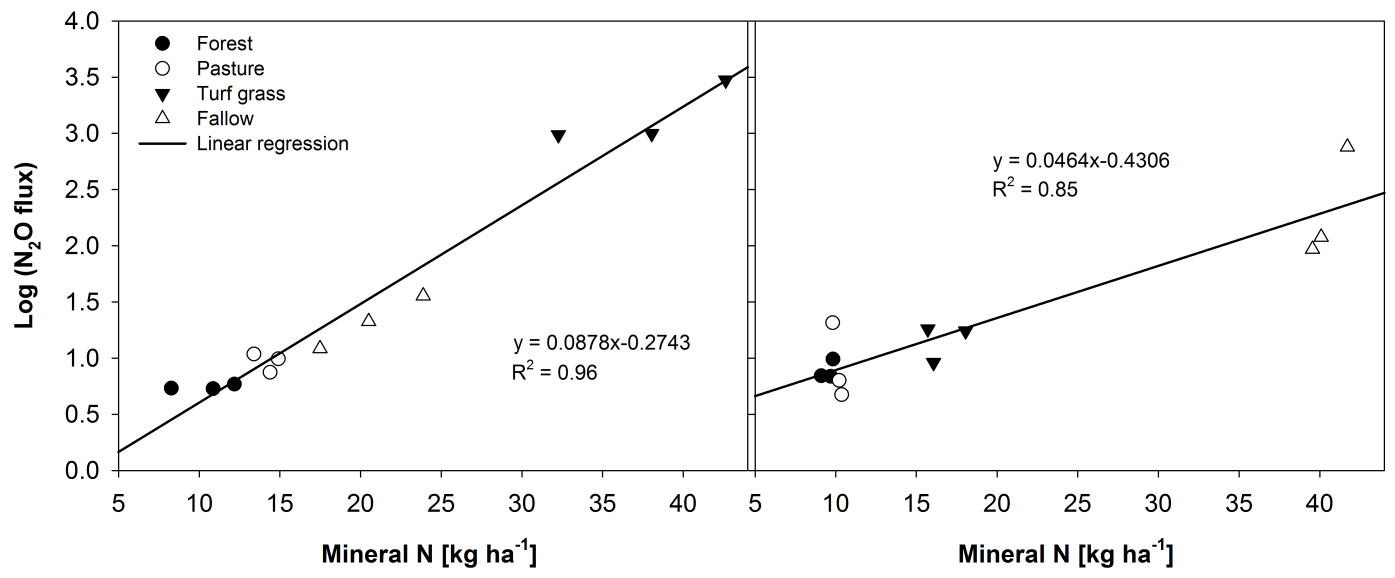

Figure 4. Linear relationship of log-transformed $\mathrm{N}_{2} \mathrm{O}$ emissions with mineral $\mathrm{N}$ content at $20 \mathrm{~cm}$ soil depth for each replicate of forest, pasture, turf grass, and fallow land use during the establishment phase (a) and the rest of the year (b), with the coefficient of determination $R^{2}$.

\subsection{Environmental parameters influencing $\mathrm{N}_{2} \mathrm{O}$ fluxes}

Mineral $\mathrm{N}$ contents in the forest and fallow soils were not significantly correlated with $\mathrm{N}_{2} \mathrm{O}$ fluxes on a daily basis (Table 4). However, the linear regression shown in Fig. 4 identified a clear increase of $\mathrm{N}_{2} \mathrm{O}$ emissions with increasing annual mineral $\mathrm{N}$ contents for all treatments during the establishment phase as well as during the rest of the year. This relationship is supported by the substantial $\mathrm{N}_{2} \mathrm{O}$ emissions peaks from the fallow and simultaneous decrease in $\mathrm{NO}_{3}^{-}$after the two biggest rain events in November 2013 and March 2014 when WFPS reached above $70 \%$. The separate linear regression for all land uses with plant cover - i.e. forest, pasture, and turf grass - identified an even stronger relationship of mineral $\mathrm{N}$ and $\mathrm{N}_{2} \mathrm{O}$. Forest and turf grass $\mathrm{N}_{2} \mathrm{O}$ fluxes were strongly, and fluxes from the pasture and fallow moderately, correlated with their WFPS. Temperature was moderately negatively correlated with $\mathrm{N}_{2} \mathrm{O}$ fluxes as well as mineral $\mathrm{N}$ for pasture and turf grass. In the fallow temperature strongly affected mineral $\mathrm{N}$ contents but not $\mathrm{N}_{2} \mathrm{O}$ fluxes. Mineral $\mathrm{N}$ in the fallow soil was strongly negatively correlated with its WFPS mostly because of the strong negative correlation of $\mathrm{NO}_{3}^{-}$with WFPS, with $r=-0.56^{* *}$.

\section{Discussion}

This study combines the first high-frequency estimates of subtropical $\mathrm{N}_{2} \mathrm{O}$ fluxes and annual mineral $\mathrm{N}$ cycling from dry sclerophyll forests, unfertilised pastures, and turf grass lawns: the most common land uses associated with urban and peri-urban environments. The lack of high-frequency field measurements in urban and peri-urban environments makes accurate assumptions and mitigation strategies difficult. Conventional gas sampling methods most likely result in an overor underestimation of emissions, as the production and release of $\mathrm{N}_{2} \mathrm{O}$ can differ in time (Mosier et al., 1998). This research gap, together with the strong temporal variability of subtropical heavy-rain events, underlines the importance of automated high-frequency measurements to capture representative soil-atmosphere gas exchange. The subtropical climatic zone represents an often-neglected area of research, despite the subtropics covering 3.26 M ha in Australia alone, as well as large areas on the North and South American continents, Africa, and Asia. Differences between other climates and the humid subtropics are the heavy summer rains leading to high soil moisture and temperatures favourable for high soil microbial activity. Therefore this study identified mineral $\mathrm{N}$ content and WFPS as the main parameters driving $\mathrm{N}_{2} \mathrm{O}$ 
production in the soil, while studies from temperate zones report temperature as the main driver (Butterbach-Bahl and Kiese, 2005; Fest et al., 2009).

\subsection{Mineral N}

Mineralised $\mathrm{N}$ in the form of $\mathrm{NH}_{4}^{+}$and $\mathrm{NO}_{3}^{-}$determines the production and loss of $\mathrm{N}$ via $\mathrm{N}_{2} \mathrm{O}$ and depends on climatic parameters like temperature as well as substrate and oxygen availability. Nutrient mineralisation is often faster in sandy soils, but the rapid infiltration and low nutrient holding capacity of the A horizon of the Chromosol decreased the highly mobile $\mathrm{NO}_{3}^{-}$content substantially after heavy-rain events. This $\mathrm{NO}_{3}^{-}$is not only lost for plant uptake but can pollute groundwater and open waterways, resulting in eutrophication. In this study mineral $\mathrm{N}$ contents from the forest and pasture treatments where driven by annual variation in temperature and moisture contents, whereas turf grass lawn and fallow were dominated by management. The negative correlation of temperature in the pasture and turf grass can most likely be explained by the higher plant productivity during the warmer summer and spring resulting in higher plant $\mathrm{NO}_{3}^{-}$ and water uptake with increasing temperatures, subsequently reducing soil moisture conditions.

Soil mineral $\mathrm{N}$ in the SERF forest was generally low and dominated by $\mathrm{NH}_{4}^{+}$, and while less seasonally variable throughout the year than $\mathrm{NO}_{3}^{-}$, it still responded to rainfall. The overall mineral $\mathrm{N}$ reported from temperate eucalypt forest soils was double the annual SERF average of $17.6 \mathrm{~kg} \mathrm{Nha}^{-1}$, with up to $38.1 \mathrm{~kg} \mathrm{Nha}^{-1}$ reported (Fest et al., 2009, 2015; Livesley et al., 2009). However, the greater proportion of $\mathrm{NO}_{3}^{-}$in the sandy SERF soil of 3.9 compared to $0.8 \mathrm{~kg} \mathrm{Nha}^{-1}$ of temperate sandy forest soils (Livesley et al., 2009) indicates a higher mineral $\mathrm{N}$ availability in the subtropics. Average $\mathrm{NO}_{3}^{-}$contents reported from other dry sclerophyll forest are even lower at $0.02 \mathrm{~kg} \mathrm{Nha}^{-1}$ (Fest et al., 2015). The higher $\mathrm{N}$ availability is most likely due to faster soil organic matter turnover in the subtropical climate with higher temperatures in combination with the main annual rainfall. While in temperate summers it is mostly dry during the periods of high temperatures, which limits microbial activity, the humid summers in SEQ accelerate not only $\mathrm{N}$ turnover but also water and $\mathrm{N}$ uptake by plants, therefore reducing potential $\mathrm{N}$ losses. Subtropical rainforests, on the other hand, present with up to 6-times-higher mineral $\mathrm{N}$ contents $\left(>97 \mathrm{~kg} \mathrm{~N} \mathrm{ha}^{-1}\right)$ than the SERF soil, suggesting a lower $\mathrm{N}$ turnover associated with the low net primary productivity (NPP) of the dry sclerophyll forests (Rowlings et al., 2012). Overall $\mathrm{NH}_{4}^{+}: \mathrm{NO}_{3}^{-}$ratios from Australian forests indicate higher $\mathrm{NO}_{3}^{-}$availability in subtropical forest soils (3-4) than in temperate zones (28-125; Livesley et al., 2009; Rowlings et al., 2012; Fest et al., 2015). These differences in $\mathrm{N}$ availability suggest that $\mathrm{N}$ cycling in forest soils is mainly regulated by the climate as opposed to soil type and NPP.
Ammonium was the dominant mineral $\mathrm{N}$ form in the SERF pasture, similar to the forest and in line with other subtropical pastures in Australia (Rowlings et al., 2015). The SERF soil reflects the overall minor annual variability of $\mathrm{NH}_{4}^{+}$compared to $\mathrm{NO}_{3}^{-}$across most climates in Australia. The overall mineral $\mathrm{N}$ content at the SERF pasture soil was at the lower end of the reported values from both temperate and subtropical pastures, which is most likely explained by the lower clay contents at the site which fixes $\mathrm{NH}_{4}^{+}$and higher $\mathrm{N}$ inputs by legumes (Livesley et al., 2009; Rowlings et al., 2015). For example, in other extensively grazed subtropical pastures $\mathrm{NH}_{4}^{+}$annual values did not drop below $55 \mathrm{~kg} \mathrm{~N} \mathrm{ha}^{-1}$ (Rowlings et al., 2015), 3 times higher than the SERF annual $\mathrm{NH}_{4}^{+}$average. While $\mathrm{NH}_{4}^{+}$at $\mathrm{SERF}$ is comparable to temperate Australian pastures, $\mathrm{NO}_{3}^{-}$in the SERF pasture soil is at the lower end (Livesley et al., 2009). This indicates an efficient system from tied-up $\mathrm{N}$ in organic material to the plant uptake of $\mathrm{NO}_{3}^{-}$, which supports the hypothesis of an efficient $\mathrm{N}$ cycle within well-established land use.

Annual mineral $\mathrm{N}$ variations in the SERF turf grass were mainly controlled by the fertilisation events but rapidly fell back to background levels after each application. The fertiliser mineral $\mathrm{N}$ peak was particularly emphasised after the first application, where soil $\mathrm{NO}_{3}^{-}$was more than twice as much as after subsequent fertilisation events. This is possibly due to the undeveloped root system and therefore less $\mathrm{N}$ uptake as well as additional plant available $\mathrm{N}$ in the added turf grass rolls. These $\mathrm{NO}_{3}^{-}$peaks together with irrigation, which is particularly needed during turf grass establishment, imply a high $\mathrm{N}$ leaching potential, with up to $80 \mathrm{~kg} \mathrm{~N} \mathrm{ha}^{-1} \mathrm{yr}^{-1}$ reported in other Australian sandy soils (Barton et al., 2006). With the high potential of heavy-rain events in the subtropics, fertiliser rates and timing need to be considered carefully to avoid excessive $\mathrm{N}$ losses in the form of $\mathrm{NO}_{3}^{-}$displacement.

The fallow soil had the highest WFPS content throughout the year due to plant cover removal and therefore no further water uptake by the roots, creating favourable conditions for soil mineralisation and subsequent losses (Robertson and Groffman, 2007). The moist conditions together with the temperatures of the warmer season resulted in accelerated $\mathrm{N}$ turnover, and without plant uptake substantial amounts of $\mathrm{NO}_{3}^{-}$accumulated in the soil. Despite the fact that mineral $\mathrm{N}$ in the fallow soil never dropped back to 0 , substantial amounts of $\mathrm{NO}_{3}$ were lost from the topsoil after heavy-rain events, not only as $\mathrm{N}_{2} \mathrm{O}$ emissions but also through $\mathrm{NO}_{3}^{-}$ displacement into deeper soil layers. The low CEC of the sandy topsoil highlights the minor nutrient holding capacity of these soils. These potential $\mathrm{N}$ losses after heavy-rain events demonstrate the significant impact of plant cover removal and soil disturbance in peri-urban ecosystems.

\section{2 $\quad \mathrm{N}_{2} \mathrm{O}$ fluxes}

The study illustrates that land use change associated with urbanisation can significantly alter soil $\mathrm{N}$ turnover, resulting in 
elevated soil $\mathrm{N}_{2} \mathrm{O}$ emissions and increased $\mathrm{N}$ losses from the soil. During the experimental year of this study, autumn was the wettest season and therefore had the highest $\mathrm{N}_{2} \mathrm{O}$ emissions from all treatments but with different intensity from the different land use systems. Soil $\mathrm{N}_{2} \mathrm{O}$ emissions were significantly different between the investigated land use systems with the temporal variations in daily $\mathrm{N}_{2} \mathrm{O}$ fluxes and primarily controlled by WFPS. However, the linear increase of $\mathrm{N}_{2} \mathrm{O}$ emissions with increasing $\mathrm{NO}_{3}^{-}$content in the soil may be the result of higher denitrification than nitrification rates in the SERF soil. The high surface sand content of the Chromosol, combined with the moderate slope, prevents excessive water logging over long periods of time, which limits $\mathrm{N}_{2} \mathrm{O}$ gaseous losses from denitrification in saturated soil conditions.

The daily $\mathrm{N}_{2} \mathrm{O}$ average of $0.4 \mathrm{~g} \mathrm{~N}_{2} \mathrm{Oha}^{-1} \mathrm{~d}^{-1}$ from this study's subtropical dry sclerophyll forest is lower than the averages of $<1.2 \mathrm{~g} \mathrm{~N}_{2} \mathrm{O} \mathrm{ha}^{-1} \mathrm{~d}^{-1}$ reported from temperate Australian dry sclerophyll forests (Fest et al., 2009; Livesley et al., 2009). This might be explained by the overall low total $\mathrm{C}$ and $\mathrm{N}$ and the below-average rainfall during the experimental year. Considering the positive correlation of $\mathrm{N}_{2} \mathrm{O}$ emissions and $\mathrm{NO}_{3}^{-}$content in the soil, it was expected that the higher $\mathrm{NO}_{3}^{-}$availability in the SERF forest compared to the temperate dry sclerophyll forest also causes higher $\mathrm{N}_{2} \mathrm{O}$ emissions. The low WFPS, which was $>40 \%$ for most of the year, inhibited denitrification processes and therefore caused lower $\mathrm{N}_{2} \mathrm{O}$ emissions than in the temperate zones as well as increased $\mathrm{NO}_{3}^{-}$uptake during the humid subtropical summer. This efficient $\mathrm{N}$ cycling together with the low NPP of the dry sclerophyll forest and low clay content at SERF also cause lower $\mathrm{N}_{2} \mathrm{O}$ losses compared to subtropical rainforests (Rowlings et al., 2012). This study supports the general hypothesis that forest soils are minor contributors to the global $\mathrm{N}_{2} \mathrm{O}$ budget, although other $\mathrm{N}_{2} \mathrm{O}$ emission studies of Australian forest soils provide only a limited comparison of temporal $\mathrm{N}_{2} \mathrm{O}$ variability due to infrequent or short-term measurements (Fest et al., 2009, 2015; Page et al., 2011).

The annual $\mathrm{N}_{2} \mathrm{O}$ emissions from the SERF pasture are comparable to other reported extensive pastures across Australia (1-2 $\mathrm{kg} \mathrm{N} \mathrm{ha}^{-1} \mathrm{yr}^{-1}$ ) but substantially lower than unfertilised pasture in the Northern Hemisphere (Dalal et al., 2003). Annual emissions from other studies on subtropical Australian pastures have been reported to be up to $3.4 \mathrm{~kg} \mathrm{~N}_{2} \mathrm{O} \mathrm{ha}^{-1} \mathrm{yr}^{-1}$ and highly inter-annually variable depending on rainfall (Rowlings et al., 2015). This exceeded the annual $\mathrm{N}_{2} \mathrm{O}$ emissions at SERF by nearly 17 times, which may have been limited by the dry year and high sand content.

The first $\mathrm{N}_{2} \mathrm{O}$ emission peak after the turf grass's establishment caused the majority of the annual $\mathrm{N}_{2} \mathrm{O}$ emissions and was not repeated after two additional fertilisation events. This initial $\mathrm{N}_{2} \mathrm{O}$ peak can be explained by the underdeveloped root system and consequently a reduced $\mathrm{NO}_{3}^{-}$uptake by the turf grass, which together with the irrigation stimulated nitrification and denitrification and consequential $\mathrm{N}_{2} \mathrm{O}$ emis- sions. The high $\mathrm{N}$ demand from the highly productive turf grass later on results in the immediate uptake of mineral $\mathrm{N}$ and therefore minor $\mathrm{N}_{2} \mathrm{O}$ emissions. The annual $\mathrm{N}_{2} \mathrm{O}$ emissions from the SERF's turf grass are more than double the $\mathrm{N}_{2} \mathrm{O}$ emissions from extensive Australian pastures reported in the literature (Dalal et al., 2003). The SERF turf grass lawn emitted on average about 3.3-times-more $\mathrm{N}_{2} \mathrm{O}$ daily during the experimental year than native pasture from the temperate zones, but only half of the reported values for urban turf grass in the USA which were comparable to intensive agriculture (Kaye et al., 2004). However, compared to Australian intensively managed pastures, $\mathrm{N}_{2} \mathrm{O}$ emissions from the SERF turf grass were $50 \%$ lower (Scheer et al., 2011). Differences between reported values and the SERF turf grass are most likely explained by differences in texture and the total $\mathrm{N}$ content in the SERF soil being nearly 4 times lower. Reported EFs from temperate pastures also vary substantially between experimental years due to differences in received rainfall (Jones et al., 2005). It could therefore be expected that the SERF's turf grass EF will increase in wetter years. However, in subtropical systems it has been proven that the total amount of annual rainfall received is not as decisive for annual $\mathrm{N}_{2} \mathrm{O}$ emissions as rainfall patterns and intensities (Rowlings et al., 2015). These differences between temperate and subtropical $\mathrm{N}$ cycling make short-term $\mathrm{N}_{2} \mathrm{O}$ flux measurements difficult to compare, and further investigation is needed in the global subtropics.

Significantly higher $\mathrm{NO}_{3}^{-}$contents occurred 3 months after plant cover removal in the fallow soil, but only during the warm and wet summer season were substantial $\mathrm{N}_{2} \mathrm{O}$ emissions observed. The two significant $\mathrm{N}_{2} \mathrm{O}$ emission peaks from the fallow were most likely caused by denitrification processes from the accumulated $\mathrm{NO}_{3}^{-}$and soil moisture conditions after major rain events. These $\mathrm{N}_{2} \mathrm{O}$ emission peaks mirror the $\mathrm{NO}_{3}^{-}$decrease from the soil after those rain events but cannot completely account for it, suggesting that most $\mathrm{NO}_{3}^{-}$was leached below $20 \mathrm{~cm}$ soil depths or lost via other gases such as $\mathrm{N}_{2}$. All other treatments, including the fertilised turf grass, prevented potential $\mathrm{N}_{2} \mathrm{O}$ production in the soil by rapid $\mathrm{NO}_{3}^{-}$uptake from plants. Therefore, plant cover removal makes ecosystems undergoing land use change most vulnerable to substantial $\mathrm{N}$ losses under humid subtropical climate conditions.

\subsection{Effect of land use change associated with urbanisation}

This study determined that urbanisation-related land use change results in an accumulation of $\mathrm{NO}_{3}^{-}$in fallow topsoil and elevated $\mathrm{N}_{2} \mathrm{O}$ emissions, mainly after heavy-rain events. The results presented here verify that subtropical $\mathrm{N}_{2} \mathrm{O}$ emissions positively correlate with mineral $\mathrm{N}$ content in the soil and therefore indicate that land use change increases $\mathrm{N}_{2} \mathrm{O}$ emissions from the soil, especially after plant cover removal and establishment of fertilised turf grass lawn. The annual 
variation in daily $\mathrm{N}_{2} \mathrm{O}$ fluxes confirms that, despite soil moisture as the strongest climatic parameter influencing $\mathrm{N}_{2} \mathrm{O}$ emissions, the individual land use is the main influence on the soil-atmosphere gas exchange. Extended periods of fallow soil in particular should be avoided during urbanisation processes as bare soil is highly vulnerable to $\mathrm{N}$ losses due to plant cover removal. Turf grass lawn, as a fertilised and highly managed land cover, leads to significantly changed soil conditions compared to the forest and pasture land use types. However, this turf grass lawn in the subtropical climate of SEQ has lower emissions against expectations based on the high-emission findings from temperate zones (Kaye et al., 2004; Tratalos et al., 2007; Grimm et al., 2008). Substantial $\mathrm{N}_{2} \mathrm{O}$ emissions were only observed within the first 2 months after turf grass establishment, while over the remaining 10 months only minor fluxes occurred even after further fertilisation events. While $\mathrm{N}_{2} \mathrm{O}$ emissions from the turf grass were reduced substantially over time, emissions from the fallow increased with time due to more available $\mathrm{NO}_{3}^{-}$. Therefore, the $\mathrm{N}_{2} \mathrm{O}$ emissions of well-established turf grass lawns need to be considered separately to their production and establishment phase as well as potential $\mathrm{N}$ losses from fallow land targeted for the entire duration of land use change, which should be kept as short as possible (Barton et al., 2006; van Delden et al., 2016).

Research from temperate zones suggests a $\mathrm{C}$ sequestration potential from the higher productivity of turf grass lawns (Golubiewski, 2006; Lorenz and Lal, 2009; Raciti et al., 2011). Others argue that the positive effect of $C$ sequestration can easily be offset by the high $\mathrm{N}$ demand together with irrigation, resulting in increased $\mathrm{N}_{2} \mathrm{O}$ emissions and overall nutrient losses caused by management practices like mowing and clipping removal (Conant et al., 2005; Wang et al., 2014). Australian ecosystems with highly weathered soils, however, are generally low in nutrient stocks and often limited in their C sequestration potential (Livesley et al., 2009). The SERF turf grass, however, presented relatively low $\mathrm{N}_{2} \mathrm{O}$ emissions when excluding the establishment phase, which implies the potential to balance emissions with $\mathrm{C}$ sequestration. A full life cycle assessment needs to determine if turf grass lawn in the subtropics is increasing or decreasing the GWP of periurban environments by balancing $\mathrm{C}$ sequestration and GHG emissions, not only from the soil but also through the production; distribution; and use of fertiliser, fuel, and chemicals (Selhorst and Lal, 2011).

\section{Conclusions}

This study provides evidence that land use change associated with urbanisation accelerates $\mathrm{N}$ turnover and increases $\mathrm{N}_{2} \mathrm{O}$ emissions from soils by presenting the first high-temporalfrequency data set on peri-urban soils in the subtropics for a full year after land use change. These findings demonstrate that GHG emissions from peri-urban areas should be in- cluded into future IPCC climate change scenarios, and ruralto-urban land development guidelines need to be established for GHG emission mitigation. Three main factors need to be considered to target $\mathrm{N}_{2} \mathrm{O}$ losses from soils during land use change associated with urbanisation: (i) previous land use, (ii) duration of development process, and (iii) new land use purpose that it is being changed into, i.e. public or private. The dry sclerophyll forest in this study supports the general hypothesis that forest soils are low $\mathrm{N}_{2} \mathrm{O}$ emitters, contrary to expectation that the humid subtropical summer conditions would increase emissions compared to temperate forest soils. The accumulation of $\mathrm{NO}_{3}^{-}$in fallow soil increases the potential for $\mathrm{N}_{2} \mathrm{O}$ emissions, which may be amplified considering future predictions of rising temperatures and more frequent heavy-rain events worldwide. Increased fertiliser application may be required to compensate for these $\mathrm{N}$ losses after land use change to keep land uses, such as turf grass, highly productive while altering $\mathrm{N}$ cycling in peri-urban environments. The outcomes of this study highlight the substantial $\mathrm{NO}_{3}^{-}$ accumulation in soils during land use change, which consequently increases $\mathrm{N}_{2} \mathrm{O}$ emissions and should be accounted for in global climate forecasts as urbanisation processes are predicted to increase worldwide with increasing population growth.

\section{Data availability}

The data set "Greenhouse gas emissions from peri-urban land use at SERF, SEQ, 2013-2015" can be found online at the $\mathrm{N}_{2} \mathrm{O}$ network at http://www.N2O.net.au/knb/metacat/ vandelden.3.3/html.

Acknowledgements. This study was undertaken at the Samford Ecological Research Facility (SERF) one of the supersites in the Terrestrial Ecosystem Research Network (TERN). The study was supported by the Institute for Future Environments (IFE) of the Queensland University of Technology (QUT).

Edited by: A. Ibrom

Reviewed by: two anonymous referees

\section{References}

ABS: 7106.0 - Australian Farming in Brief, edited by: Australian Bureau of Statistics, Canberra, 2012.

AGO: National Inventory Report 2008, National Greenhouse Account, Australian Greenhouse Office, Commonwealth of Australia, Canberra, 2010.

Baldock, J. A., Wheeler, I., McKenzie, N., and McBrateny, A.: Soils and climate change: potential impacts on carbon stocks and greenhouse gas emissions, and future research for Australian agriculture, Crop Pasture Sci., 63 3, 269-283, doi:10.1071/cp11170, 2012. 
Barton, L., Wan, G. G. Y., and Colmer, T. D.: Turfgrass (Cynodon dactylon L.) sod production on sandy soils, II. Effects of irrigation and fertiliser regimes on N leaching, Plant Soil, 284, 147164, 2006.

Betts, R.:Implications of land ecosystem-atmosphere interactions for strategies for climate change adaptation and mitigation, Tellus B, 59, 602-615, 2007.

BOM: Commonwealth Bureau of Meteorology, Australian Government, 2015.

Butterbach-Bahl, K. and Kiese, R.: Significance of forests as sources for $\mathrm{N}_{2} \mathrm{O}$ and $\mathrm{NO}$, in: Tree species effects on soils: implications for global change, Springer, 173-191, 2005.

Carter, R. and Gregorich, E. G.: Soil Sampling and Methods of Analysis, Second Edition, edited by: Canadian Society of Soil Science, Taylor \& Francis, 2007.

Conant, R. T., Paustian, K., Del Grosso, S. J., and Parton, W. J.: Nitrogen pools and fluxes in grassland soils sequestering carbon, Nutr. Cycl. Agroecosys., 71, 239-248, doi:10.1007/s10705-0045085-z, 2005

Dalal, R. C., Wang, W. J., Robertson, G. P., and Parton., W. J.: Nitrous oxide emission from Australian agricultural lands and mitigation options: a review, Aust. J. Soil Res., 41, 165-195, doi:10.1071/sr02064, 2003.

Fest, B. J., Livesley, S. J., Drösler, M., van Gorsel, E., and Arndt, S. K.: Soil-atmosphere greenhouse gas exchange in a cool, temperate Eucalyptus delegatensis forest in southeastern Australia, Agr. Forest Meteorol., 149, 393-406, doi:10.1016/j.agrformet.2008.09.007, 2009.

Fest, B. J., Livesley, S. J., von Fischer, J. C., and Arndt, S. K.: Repeated fuel reduction burns have little long-term impact on soil greenhouse gas exchange in a dry sclerophyll eucalypt forest, Agr. Forest Meteorol., 201, 17-25, doi:10.1016/j.agrformet.2014.11.006, 2015.

Golubiewski, N. E.: Urbanization increases grassland carbon pools: Effects of landscaping in Colorado's front range, Ecol. Appl., 16, 555-571, doi:10.1890/10510761(2006)016[0555:uigcpe]2.0.co;2, 2006.

Grimm, N. B., Foster, D., Groffman, P., Grove, J. M., Hopkinson, C. S., Nadelhoffer, K. J., Pataki, D. E., and Peters., D. P. C.: The changing landscape: ecosystem responses to urbanization and pollution across climatic and societal gradients, Front. Ecol. Environ., 6, 264-272, 2008.

Groffman, P. M. and Pouyat, R. V.: Methane Uptake in Urban Forests and Lawns, Environ. Sci. Technol., 43, 5229-5235, doi:10.1021/es803720h, 2009.

Grover, S. P. P., Livesley, S. J., Hutley, L. B., Jamali, H., Fest, B., Beringer, J., Butterbach-Bahl, K., and Arndt, S. K.: Land use change and the impact on greenhouse gas exchange in north Australian savanna soils, Biogeosciences, 9, 423-437, doi:10.5194/bg-9-423-2012, 2012.

Hart, S. C., Stark, J. M., Davidson, E. A., and Firestone, M. K.: Nitrogen mineralization, immobilization, and nitrification, Methods of Soil Analysis: Part 2 - Microbiological and Biochemical Properties, 985-1018, 1994.

IPCC: Chapter 8: Settlements in Guidelines for National Greenhouse Gas Inventories: Agriculture, Forestry and Other Land Use, edited by: Ginzo, H. D., Jenkins, J. C., Ogle, S. M., Verchot, L. V., Handa, M., and Tsunekawa, A., 4, available at: http://www.ipcc-nggip.iges.or.jp/public/2006gl/pdf/4_
Volume4/V4_08_Ch8_Settlements.pdf (last access: 1 January 2016), 2006.

IPCC: Climate Change 2013: The Physical Science Basis, Contribution of Working Group I to the Fifth Assessment Report of the Intergovernmental Panel on Climate Change, edited by: Stocker, T. F.,, Qin, Plattner, G.-K., Tignor, M., Allen, S. K., Boschung, J., Nauels, A., Xia, Y., Bex, V., and Midgley, P. M., Cambridge University Press, Cambridge, United Kingdom and New York, NY, USA, 1535 pp., doi:10.1017/CBO9781107415324, 2013.

Isbell, R.: The Australian soil classification, CSIRO publishing: Collingwood, 4, 2002.

Jones, S. K., Rees, R. M., Skiba, U. M., and Ball, B. C.: Greenhouse gas emissions from a managed grassland, Global Planet. Change, 47, 201-211, doi:10.1016/j.gloplacha.2004.10.011, 2005.

Kaye, J. P., Burke, I. C., Mosier, A. R., and Guerschman, J. P.: Methane and nitrous oxide fluxes from urban soils to the atmosphere, Ecol. Appl., 14, 975-981, doi:10.1890/03-5115, 2004.

Kaye, J. P., Groffman, P. M., Grimm, N. B., Baker, L. A., and Pouyat, R. V.: A distinct urban biogeochemistry?, Trends Ecol. Evol., 21, 192-199, 2006.

Knowles, T. A. and Singh, B.: Carbon storage in cotton soils of northern New South Wales, Aust. J. Soil Res., 41, 889-903, doi:10.1071/sr02023, 2003.

Kroeze, C., Mosier, A., Nevison, C., Oenema, O., Seitzinger, S., and van Cleemput, O.: Revised 1996 IPCC guidelines for national greenhouse gas inventories: Intergovernmental Panel on Climate Change, 1997.

Livesley, S. J.,, Kiese,, Miehle, Weston, C. J., Butterbach-Bahl, K., and Arndt, S. K.: Soil-atmosphere exchange of greenhouse gases in a Eucalyptus marginata woodland, a clovergrass pasture, and Pinus radiata and Eucalyptus globulus plantations, Glob. Change Biol., 15, 425-440, doi:10.1111/j.13652486.2008.01759.x, 2009.

Lorenz, K. and Lal, R.: Biogeochemical $\mathrm{C}$ and $\mathrm{N}$ cycles in urban soils, Environ. Int., 35, 1-8, 2009.

Milesi, C., Running, S. W., Elvidge, C. D., Dietz, J. B., Tuttle, B. T., and Nemani, R. R.: Mapping and modeling the biogeochemical cycling of turf grasses in the United States, Environ. Manage., 36, 426-438, doi:10.1007/s00267-004-0316-2, 2005.

Moreton Bay Regional Council:Community profile, Samford valley area, http://profile.id.com.au/Default.aspx?id=311\&pg= 101\&gid=560\&type=enum (last access: 1 Janaury 2016), 2011.

Mosier, A., Kroeze, C., Nevison, C., Oenema, O., Seitzinger, S., and Van Cleemput, O.: Closing the global $\mathrm{N}_{2} \mathrm{O}$ budget: nitrous oxide emissions through the agricultural nitrogen cycle, Nutr. Cycl. Agroecosys., 52, 225-248, 1998.

Page, K. L., Dalal, R. C., and Raison R. J.: The impact of harvesting native forests on vegetation and soil $\mathrm{C}$ stocks, and soil $\mathrm{CO}_{2}, \mathrm{~N}_{2} \mathrm{O}$ and $\mathrm{CH}_{4}$ fluxes, Aust. J. Bot., 59, 653-668, doi:10.1071/bt11207, 2011.

Pataki, D. E., Xu, T., Luo, Y. Q., and Ehleringer, J. R.: Inferring biogenic and anthropogenic carbon dioxide sources across an urban to rural gradient, Oecologia, 152, 307-322, 2007.

Potere, D. and Schneider, A.: A critical look at representations of urban areas in global maps, GeoJournal, 69, 55-80, 2007.

Raciti, S. M., Groffman, P. M., Jenkins, J. C., Pouyat, R. V., Fahey, T. J., Pickett, S. T. A., and Cadenasso, M. L.: Accumulation of carbon and nitrogen in residential soils with different land-use 
histories, Ecosystems, 14, 287-297, doi:10.1007/s10021-0109409-3, 2011a.

Rayment, G. E. and Higginson F. R.: Australian laboratory handbook of soil and water chemical methods: Inkata Press Pty Ltd, 1992.

Robertson, G. P. and Groffman, P.: Nitrogen transformations, edited by: Paul, E. A. C. F., Soil Microbiology, Ecology, and Biochemistry, Oxford, UK, Elsevier Academic Press, 341-364, 2007.

Rowlings, D. W., Grace, P. R., Kiese, R., and Weier, K. L.: Environmental factors controlling temporal and spatial variability in the soil-atmosphere exchange of $\mathrm{CO}_{2}, \mathrm{CH}_{4}$ and $\mathrm{N}_{2} \mathrm{O}$ from an Australian subtropical rainforest, Glob. Change Biol., 18, 726-738, doi:10.1111/j.1365-2486.2011.02563.x, 2012.

Rowlings, D. W., Grace, P. R., Scheer, C., and Kiese, R.: Influence of nitrogen fertiliser application and timing on greenhouse gas emissions from a lychee (Litchi chinensis) orchard in humid subtropical Australia, Agr. Ecosyst. Environ., 179, 168-178, 2013.

Rowlings, D. W., Grace,P. R., Scheer, C., and Liu, S.: Rainfall variability drives interannual variation in $\mathrm{N}_{2} \mathrm{O}$ emissions from a humid, subtropical pasture, Sci. Total Environ., 512, 8-18, 2015.

Scheer, C., Wassmann, R., Kienzler, K., Ibragimov, N., and Eschanov, R.: Nitrous oxide emissions from fertilized, irrigated cotton (Gossypium hirsutum L.) in the Aral Sea Basin, Uzbekistan: Influence of nitrogen applications and irrigation practices, Soil Biol. Biochem., 40, 290-301, 2008.

Scheer, C., Grace, P. R., Rowlings, D. W., Kimber, S., and Van Zwieten, L.: Effect of biochar amendment on the soil-atmosphere exchange of greenhouse gases from an intensive subtropical pasture in northern New South Wales, Australia, Plant Soil, 345, 47-58, doi:10.1007/s11104-011-0759-1, 2011.

Scheer, C., Grace, P. R., Rowlings, D. W., and Payero J.: Soil $\mathrm{N}_{2} \mathrm{O}$ and $\mathrm{CO}_{2}$ emissions from cotton in Australia under varying irrigation management, Nutr. Cycl. Agroecosys., 95, 43-56, doi:10.1007/s10705-012-9547-4, 2013.
Scheer, C., Rowlings, D. W., Firrel, M., Deuter, P., Morris, S., and Grace, P. R.: Impact of nitrification inhibitor (DMPP) on soil nitrous oxide emissions from an intensive broccoli production system in sub-tropical Australia, Soil Biol. Biochem., 77, 243-251, 2014.

Selhorst, A. L. and Lal, R.: Carbon budgeting in golf course soils of Central Ohio, Urban Ecosystems, 14, 771-781, doi:10.1007/s11252-011-0168-5, 2011.

Tratalos, J., Fuller, R. A., Warren, P. H., Davies, R. G., and Gaston, K. J.: Urban form, biodiversity potential and ecosystem services, Landscape Urban Planning 83, 308-317, 2007.

Turf Australia: Newsletter 2012, available at: https://www. turfaustralia.com.au/ (last access: 1 January 2016), 2012.

United Nations: World urbanization prospects: The 2007 Revision, edited by: Economics and Social Affairs, United Nations (NY): United Nations Population Division, 2008.

United Nations: World Population Prospects: The 2012 Revision, Highlights ans Advance Tables, edited by Economics and Social Affairs, United Nations (NY), United Nations Population Divisio, 2013

van Delden, L.: Greenhouse gas emissions from peri-urban land use at SERF, SEQ, Australia, 2013-2015, Research Data Australia: $\mathrm{N}_{2} \mathrm{O}$ Network, available at: http://www.N2O.net.au/knb/ metacat/vandelden.3.3/html, 2015.

van Delden, L., Larsen, E., Rowlings, D., Scheer, C., and Grace, P.: Establishing turf grass increases soil greenhouse gas emissions in peri-urban environments, Urban Ecosystems, 19, 749-762, 2016.

Wang, Y., Tu, C., Li, C., Tredway, L., Lee, D., Snell, M., Zhang, X., and Hu, S.: Turfgrass Management Duration and Intensities Influence Soil Microbial Dynamics and Carbon Sequestration., Int. J. Agr. Biol., 16, 139-145, 2014.

WRB: IUSS Working Group, World Reference Base for Soil Resources 2014, update 2015, World Soil Resources Reports No. 106, International soil classification system for naming soils and creating legends for soil maps, FAO, Rome, 2015. 